\title{
エッジインデンテーション法による溶射皮膜のはく離強度評価
}

中 佐 啓治郎* 加 藤 昌 彦*
張 東 坤 $^{* *}$ 田 坂 圭一郎**

\section{Evaluation of Delamination Strength of Thermally Sprayed Coating by Edge-Indentation Method}

by

\author{
Keijiro NAKASA ${ }^{*}$, Masahiko KATO ${ }^{*}$, Dongkun Z HANG $^{*}$ \\ and Keiichiro TASAKA **
}

In order to evaluate the shear-delamination strength of thermally sprayed coatings, an "edge-indentation method" was newly proposed in the present study, and the method was applied to WC-Co coating deposited on a tool steel (JIS:SKD5) specimen by high-velocity flame spraying and $\mathrm{Al}_{2} \mathrm{O}_{3}-\mathrm{TiO}_{2}$ coating on a mild steel (JIS : SS400) specimen by plasma spraying. The delamination energy of coating, $E_{d}$, is defined by the following equation based on the indentation load $P$ vs. displacement $\delta$ curve:

$$
E_{d}=\frac{\int_{0}^{\delta_{0}} P \cdot d \delta-\int_{0}^{\delta_{0}-B_{1}} P^{\prime} \cdot d \delta}{S} \times \frac{2 \theta}{2 \pi}
$$

Where $\delta_{0}$ is the displacement at delamination, $B_{1}$ is the coating thickness, $S$ is the delamination area, $2 \theta$ is the delamination angle and $P^{\prime}$ is the indentation load only for substrate. The delamination energy $E_{d}$ of WC-Co coating obtained by experiment reveals almost the same value irrespective of coating thickness $B_{1}$ and relative indentation distance from edge $x / B_{1}$. The $E_{d}$ of $\mathrm{Al}_{2} \mathrm{O}_{3}-\mathrm{TiO}_{2}$ coating increases slightly with an increase in $B_{1}$, and the $E_{d}$ is smaller than that of WC-Co coating. The edge-indentation method is effective to evaluate the shear-delamination strength especially when the substrate is very hard.

Key words : Delamination strength, Thermal spray coating, Edge-indentation method, Load-displacement curve, Delamination area.

\section{1 緒 言}

金属材料の耐摩耗性，耐熱性，耐食性などの表面特性 を改善するため, 各種溶射法が広く用いられているが, ${ }^{1), 2)}$ 溶射部材が使用時に応力サイクル，熱サイクル，粒子衝 突などを受けると，皮膜と基材の界面にはく離が生じる ことがある，一度皮膜のはく離が起こると，基材が直接 環境にさらされて部材全体の使用寿命および信頼性は著 しく低下するから，皮膜のはく離を防止することは重要 な課題である。そのため，高性能皮膜の開発とともに， はく離強度を簡便にしかも定量的に評価できる方法の確 立が望まれている。

溶射皮膜と基材の界面強度を評価する方法としては， JIS 規格の皮膜に垂直な荷重を加える引張試験，スクラ ッチ試験，膜のひきはがし試験，落錘試験，折り曲げ試

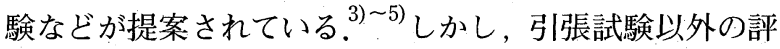
価法は定性的な試験法であり，得られた值の物理的意味 は必ずしも明確ではない，また，引張試験においても接 着剤の強度不足，コーティング材と界面への接着剤の浸 透などの問題が生じる場合がある。さらに，実際に溶射 皮膜がはく離する主原因は皮膜と基材の界面に発生する
せん断応力であるが，コーティング材に別の板を接着剤 で貼り付けて両者を引張る形式の引張せん断試験法でも 上記のような問題が生じるし，円筒を用いるせん断はく 離試験)においても，膜厚が薄い場合や溶射にようて試 験片寸法に狂いが生じる場合には評価が非常に困難であ る、著者らは，この問題を解決するため，皮膜に平行な 引張荷重を加える評価法 ${ }^{6)}$ 吕提案した。この方法は， 破壊力学的手法に基づいてせん断はく離強度（厳密には 引張り一せん断混合モードはく離強度）を定量的に測定 できる長所があり，溶射皮膜の開発，溶射条件の設定に は有効であるが，皮膜のはく離を基材の塑性変形によっ て生じさせるので, 金型やロールなど基材の変形能が小 さい実部品について，はく離強度を直接測定することは できない，そこで本研究では，コーティング皮膜に人工 的に端部を導入し，その近傍にダイヤモンド圧子を押し 込むことによりせん断はく離強度を評価する「エッジイ ンデンテーション法」を開発し，その有效性と問題点を 明らかにするため, 高速フレーム溶射した WC-Co サー メット皮膜およびプラズマ溶射した $\mathrm{Al}_{2} \mathrm{O}_{3}-\mathrm{TiO}_{2}$ セラミッ ク皮膜のはく離強度評価を試みた。

$\dagger \quad$ 原稿受理 平成 9 年 7 月30日 Received July 30, 1997

* 正 会 員 広島大学工学部第一類（機械系） ₹739-8527 東広島市鏡山, Dept. of Mech. Eng. Hiroshima Univ., Kagamiyama, HigashiHiroshima, 739-8527

** 広島大学大学院 ７.739-8527 東広島市鏡山, Graduate Student, Hiroshima Univ., Kagamiyama, Higashi-Hiroshima, 739-8527 


\section{$2 \cdot 1$ 試験片および溶射法}

\section{2 実 験 方 法}

本研究では，硬質基材として熱間加工用合金工具鋼 ( SKD5，化学組成（質量 \%)：0.30\%C，0.25\%Si， $0.019 \% \mathrm{P}, 0.004 \% \mathrm{~S}, 2.46 \% \mathrm{Cr}, 9.46 \% \mathrm{~W}, 0.34 \% \mathrm{~V}$, $0.46 \% \mathrm{Mn}$, 焼入れ : $1373 \mathrm{~K}, 1.2 \mathrm{ks}$ 保持, 油冷; 焼もど し：898K，3.6ks 保持，空冷）および軟質基材として一 般構造用圧延鋼材 SS400 を用いた。これらを Fig.1 (a) お よび (b) に示す板状の試験片基材に機械加工し，石油べ ンジンで脱脂したのち, 基材表面をショットブラストし て凹凸をつけた，本研究では 2 種類の溶射法を用いた。

(1) 高速フレーム溶射：ダイヤモンドジェット溶射装 置（スルーザーメテコ社製）を用いて WC（88 質量％)Co (12 質量 \%) 粉末を SKD5 基材に高速フレーム溶射し た，溶射条件は，溶射ガン移動速度 $: 333 \mathrm{~mm} / \mathrm{s}$ ，溶射ピ ッチ：5mm，溶射ガンと試験片の距離：250mm, 燃焼ガ ス：プロピレンガス $(580 \mathrm{kPa})+$ 酸素ガス $(1080 \mathrm{kPa})$ で ある．また，溶射ガンの往復回数を変化させることにより 膜厚 $B_{1}$ を変化させた。 なお，参考のため，ショットブラ ストを施さずに溶射した試験片も準備した。

(2) プラズマ溶射：プラズマ溶射装置を用いてアルミ ナ $\mathrm{Al}_{2} \mathrm{O}_{3}$ (60 質量％)-チタニァ $\mathrm{TiO}_{2}$ （40 質量％）混合粉 末（粒子直径： $10 〜 40 \mu \mathrm{m}$ ）を SS400 基材に溶射した. 溶射条件は，電圧：36V，電流：900A，アークガス拈よ びパウダーガス：アルゴン（圧力 $470 \mathrm{kPa}$ ), 二次ガス：

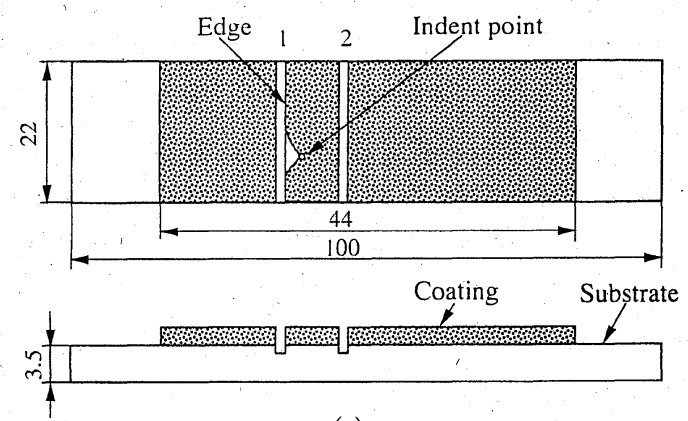

(a)

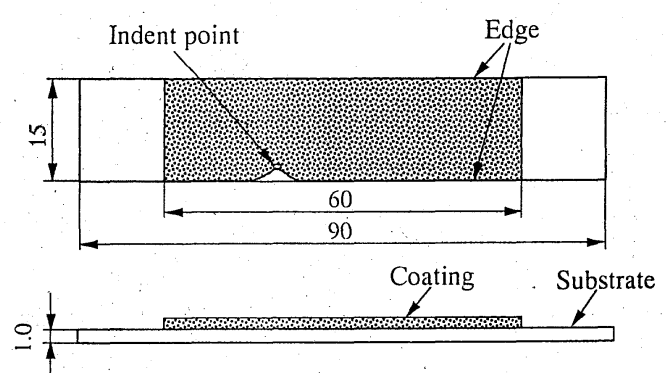

(b)

unit: mm

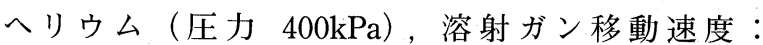
$670 \mathrm{~mm} / \mathrm{s}$, 溶射距離 : $100 \mathrm{~mm}$ であり, ホッパー回転数 を変えて溶射量を調整し, 膜厚 $B_{1}$ を変化させた.

高速フレーム溶射試験片（WC-Co 皮膜）については， 放電加工により Fig. 1 (a) に示すような幅 $1 \mathrm{~mm}$ の溝（エ ッジ）を設けた。この時, 皮膜エッジ部界面が放電加工 の影響をできるだけ受けないようにするため, 放電電圧は 低く設定した．その後皮膜エッジ近傍の所定の位置に圧 子を押し込んでインデンテーション試験を行い，エッジ部 に試験領域がなくなると, 次の新たな溝を設けることによ り, 1 枚の試験片で多数回のエッジインデンテーション試 験を行った。プラズマ溶射試験片 $\left(\mathrm{Al}_{2} \mathrm{O}_{3}-\mathrm{TiO}_{2}\right.$ 皮膜 $)$ の 場合には放電加工によりエッジを設けることができないの で，グリーンカーボランダム切断砥石で皮膜および基材を 切断して Fig. 1 (b) に示すような短冊状試験片を作製し; そのエッジ近傍にインデンテーションを行った。

\section{$2 \cdot 2$ エッジインデンテーション試験}

Fig. 2 に模式的に示すように, 圧縮試験機の移動台上 に試験片を置き, Fig. 3 に示すように頂角 120 度の円錐ダ イヤモンド圧子（ロックウェル C 硬さ試験用）を皮膜の エッジから一定距離 $x$ の位置に押しつけた。ロードセルに より荷重 $P$ を, 移動ステージと圧子ホルダーの間に取り 付けたクリップゲージにより押し込み変位 $\delta$ を測定し,両 者を X-Yレコーダーで記録して, 荷重 - 変位曲線を得た。

Fig. 4 (a) および (b) は，皮膜厚さの異なる WC-Co 皮

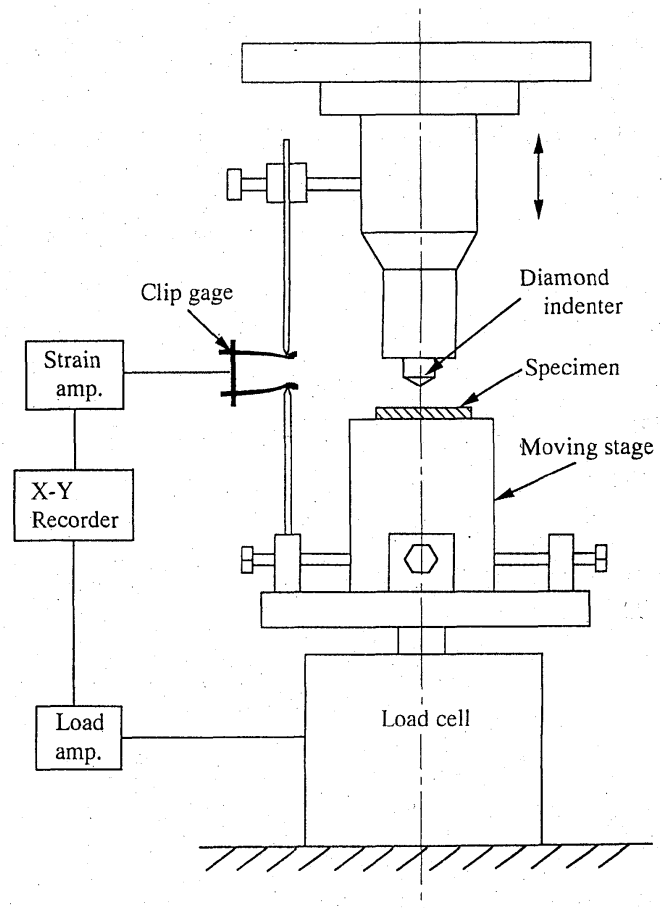

Fig. 1. Specimens with edge for (a) WC-Co coating and (b) $\mathrm{Al}_{2} \mathrm{O}_{3}-\mathrm{TiO}_{2}$ coating.

Fig. 2. Indentation apparatus. 


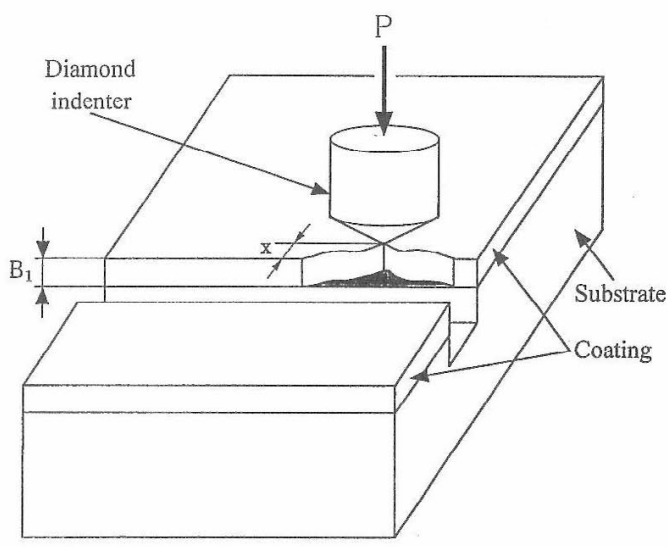

Fig. 3. Detail of indentation position near edge.

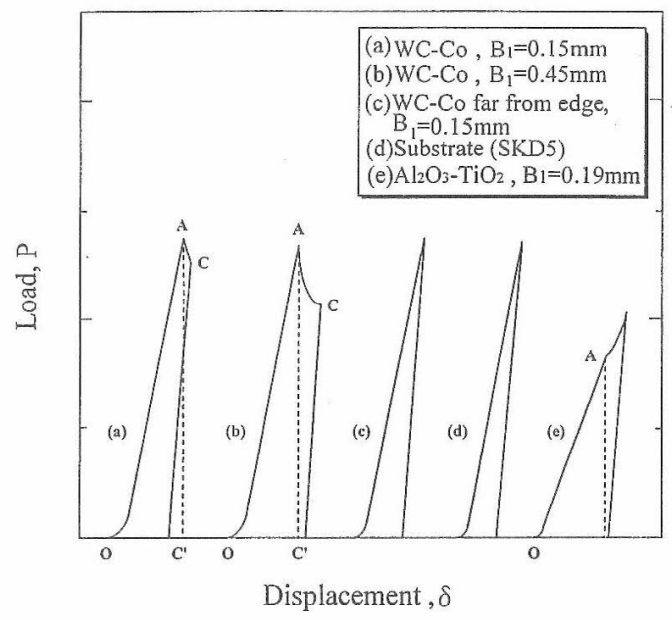

Fig. 4. Load-displacement curves.

膜試験片について得られた荷重一変位曲線の模式図であ る。圧子を試験片に押しつけていくと荷重と变位が增加 するが，A 点で皮膜がはく離すると同時にC 点まで荷重 が急激に減少する。荷重の低下量は膜厚が厚いほど大き わ. C 点で試験機を停止して除荷すると, 荷重は $\mathrm{CC}^{\prime}$ 線 のように弾性ひず炎を回復しながら低下する。 Fig. 4 (c) は，エッジから遠く離れた位置でのインデンテーション 負荷打よひ除荷曲線であり，この場合は圧子を基材に深 く押し込んでも皮膜の圧壞は生じるがはく離は生じない。 Fig. 4 (d) は基材のみのインデンテーション曲線である。 Fig. 4 (e) は $\mathrm{Al}_{2} \mathrm{O}_{3}-\mathrm{TiO}_{2}$ 皮膜の荷重一変位曲線の例で, 圧子が基材にかなり深く進入したのちに $\mathrm{A}$ 点で皮膜のは く離が起こるが, 荷重の低下は見られない。また負荷曲 線の勾配はWC-Co 皮膜の場合に比べてかなり小さい。

Fig. 5 は, WC-Co 皮膜はく離面の拡大写真である。こ れによると，圧子直下の皮膜は吕のまま残って和り，は く離き裂は压子先端からではなく压子周辺で発生してい る。このため, 皮膜は台形状（富士山状）にはく離して いるが，エッジに近づくにつれて広がっている（Fig. 3)。
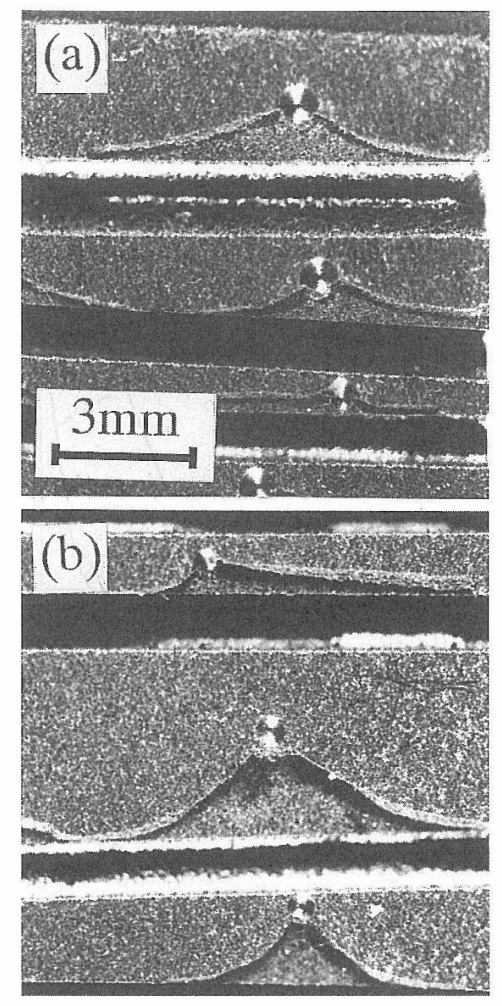

Fig. 5. Delamination of WC-Co coatings after edgeindentation tests. (a) $B_{1}=0.15 \mathrm{~mm}$, (b) $B_{1}=$ $0.25 \mathrm{~mm}$ (without shot blast).

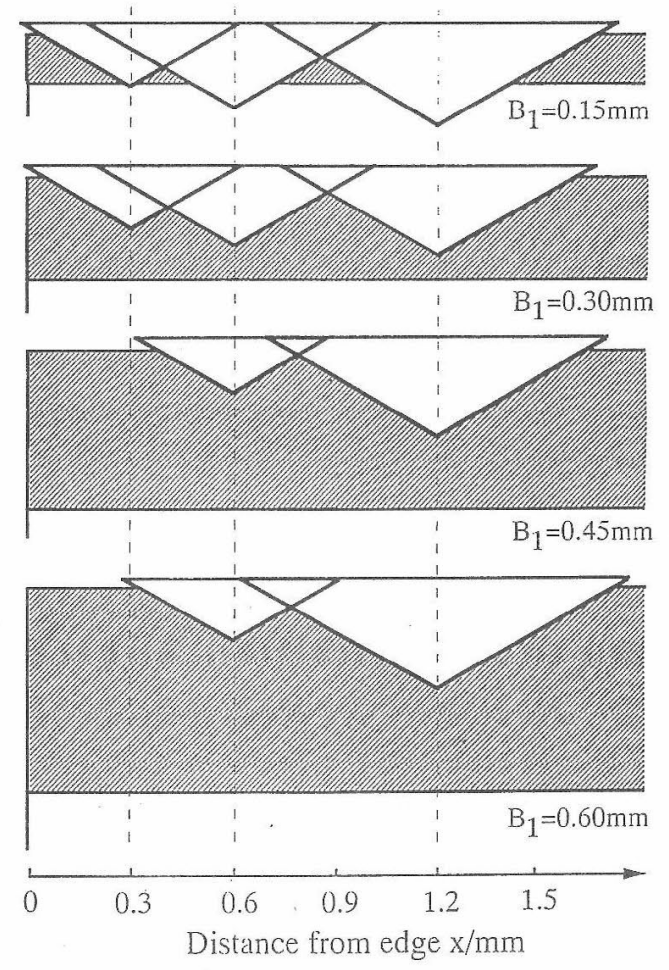

Fig. 6. Indentation depth of WC-Co coating just before delamination at various coating thickness and distance from edge. 


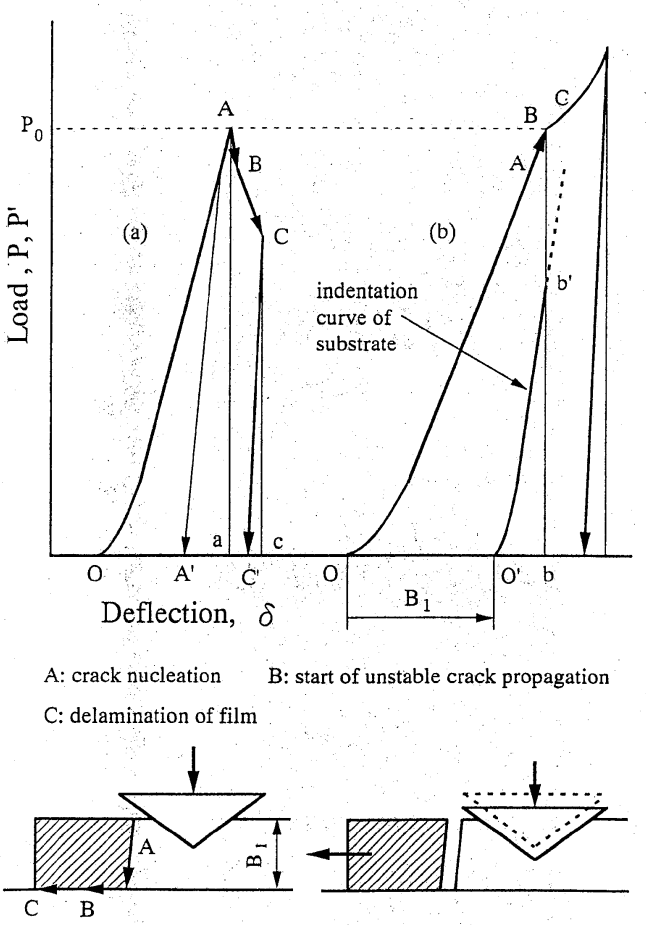

Fig. 7. Schematic crack initiation and propagation process speculated from load-displacement curve. (a) WC-Co coating, (b) $\mathrm{Al}_{2} \mathrm{O}_{3}-\mathrm{TiO}_{2}$ coating.

Fig. 6 は，WC-Co 皮膜について，実測した荷重と変位の 関係から，皮膜がはく離する直前に圧子がどの程度の深 さに達しているかを調べたものである．膜厚が小さい場 合または $x$ が大きい場合には圧子が基材に達したのちに はく離が生じるが，膜厚が比較的大きい場合には圧子が 基材に達する前にはく離が起こる。なお， $\mathrm{Al}_{2} \mathrm{O}_{3}-\mathrm{TiO}_{2}$ 皮 膜の場合には，実験に用いた皮膜厚さ $(0.11 \sim 0.30 \mathrm{~mm})$ では，すべて圧子が基材に達した後にはく離が生じる。

\section{2・3 はく離強度評価方法の提案}

上記のインデンテーション曲線から得られた情報をも とに，皮膜のはく離特性を表すエネルギーパラメーター を考える.Fig. 7 (a) および付圀は，WC-Co 皮膜（SKD5 基材）への圧子押し込みに伴う皮膜の変形（O-A），き裂 の発生と成長 $(\mathrm{A}-\mathrm{B})$, 不安定伝ぱ開始 (B 点), はく離 完了と試験機停止（C 点）および除荷過程（C-C'）を模 式的に示したものである. 皮膜に圧子を押しつけると，荷 重は OA 線にしたがって増加するが，その間に皮膜は不 可逆変形するので, A 点直下から除荷しても $\mathrm{O}$ 点ではな く $\mathrm{A}^{\prime}$ 点に戻る（その勾配は, 負荷曲線のそれよりはるか に大きい)。つぎに，き裂が不安定伝ぱを開始する B 点 を, 実測した荷重一変位曲線から見出すことは困難であ り, Fig. 7 (a)の A-B-C が実測曲線の AC として現れるが, $\mathrm{A}$ 点から $\mathrm{C}$ 点への荷重の低下は瞬時に起こるので, $\mathrm{B}$ 点 は $\mathrm{A}$ 点に極めて近いと思われる. $\mathrm{C}$ 点からの除荷曲線を C-C' とすると, この間にはく離していない皮膜および基
材に蓄えられていた弾性エネルギーが解放されるから, 結 局，はく離を生じるための有効なエネルギーとしては OABCC' の面積に相当するエネルギーということになる.

つぎに, $\mathrm{Al}_{2} \mathrm{O}_{3}-\mathrm{TiO}_{2}$ 皮膜 ( $\mathrm{SS} 400$ 基材) のインデンテ ーション曲線の模式図を Fig. 7 (b) に示す.この場合には 圧子が基材にかなり深く進入したのちに皮膜がはく離す るので，はく離が生じても荷重の急激な低下は起こらず， 曲線に折れ曲がりが生じるのみである。したがって，こ の折れ曲がり点は, 皮膜のはく離開始点 $\mathrm{B}$ 点に相当す ると思われる：また，曲線 OA の後期には皮膜の変形特 性のみならず，基材の弾性変形および塑性変形特性が反 映されている。

上記の皮膜はく離過程の考察によると, エッジインデ ンテーション法における皮膜のはく離挙動は, 皮膜の変形 特性, 皮膜の強度, 膜厚, 界面強度および基材の変形特 性によって支配されることが分かる. 本研究で用いたWCCo 皮膜と SKD5 基材の組み合わせにおいては, 皮膜の気 孔率は小さく変形抵抗が大きい（荷重一変位曲線の勾配 が大きい）ので，圧子の押し込み量が小さくても皮膜に は大きな引張応力が, 界面には大きなせん断応力が作用 する. また, 基材の強度が大きいので, 圧子が基材に達 する前には界面で塑性変形が起こることはなく, 界面の せん断応力は緩和されにくい，したがって，荷重は大きい が少ない押し込み深さで皮膜の割れと界面でのはく離が 起こる.一方, $\mathrm{Al}_{2} \mathrm{O}_{3}-\mathrm{TiO}_{2}$ 皮膜と $\mathrm{SS} 400$ 基材の組み合わ せにおいては, 皮膜が多孔質であるので, 圧子の押し込 みにより皮膜が変形しやすく（荷重一変位曲線の勾配が 小さい), 皮膜に割れが生じないままで圧子が容易に基材 に達する。基材の降伏強度は小さいので, そのまま圧子 は基材に押し込まれるが，圧子周辺に打ける皮膜と基材 の界面せん断応力は上昇し続けるので，ある荷重ではく 離が起こる. 通常の他の溶射皮膜と基材の組み合わせに おいても, 皮膜はく離時に荷重の急減または荷重一変位 曲線の折れ曲がりのいずれかが起こると思われるので, 上 記二つの典型的な組み合わせに対して得られる荷重 - 変 位曲線から，エッジインデンテーション法による一般的な はく離強度評価法を見出すことが可能であると思われる. その場合, 皮膜と基材のどのような組み合わせにおいて も, はく離荷重 $P_{0}$ は, 皮膜, 界面, 基材それぞれの特性 を含む重要なパラメータの一つであるが, 圧子が基材に達 すると, はく離荷重が基材そのものの変形挙動に直接影 響されるようになるから, 特別の扱いが必要となる.

そこで本研究では，はく離エネルギーの定義として， き裂の発生または不安定伝ぱ開始点（具体的には, WCCo 皮膜のように荷重の急減が起こる場合には A 点, $\mathrm{Al}_{2} \mathrm{O}_{3}-\mathrm{TiO}_{2}$ 皮膜のように折れ曲がり点が現れる場合には B 点）までに, 試料が受け取った弾塑性ひずみエネルギ 一とし（き裂が不安定伝ぱする間に外力がなした仕事, はく離していない皮膜部分に蓄えられたひずみエネルギ 一などは考慮しない)，圧子が基材に到達したのちにはく 離が起こる場合には, 基材を変形させるに必要な弾塑性 ひずみエネルギーを除外する，これを除外する方法は，O 


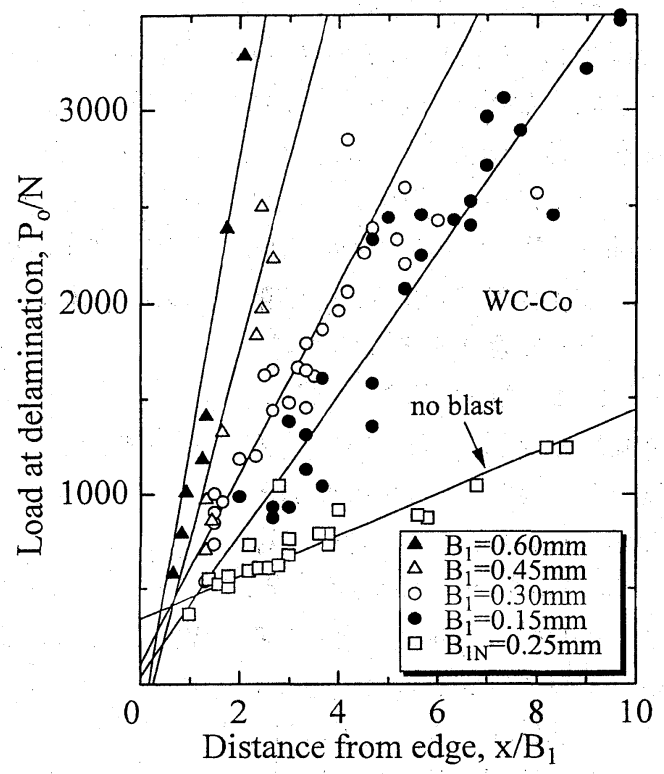

Fig. 8. Effect of coating thickness on the relation between normalized distance from edge and load at delamination for WC-Co coating.

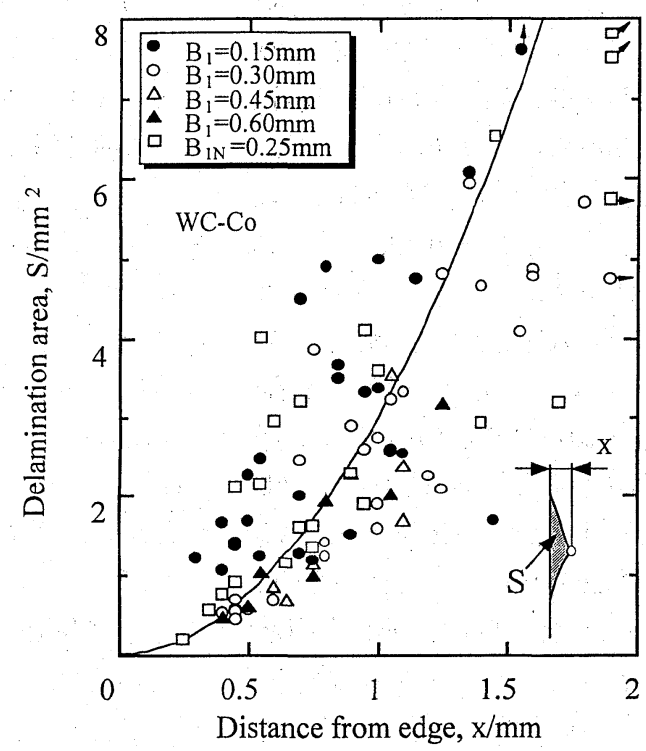

Fig. 9. Relation between distance from edge and delamination area of WC-Co coating.

点（圧子進入開始点）から膜厚 $B_{1}$ に等しい変位 $\mathrm{OO}^{\prime}$ を 決め, この $\mathrm{O}^{\prime}$ を出発点とする基材のみの荷重 $P^{\prime}$ - 変位 $\delta$ 曲線（Fig. 4 (d) の曲線に相当する）Ｏ'-b! 曲線を描き， 全エネルギーから $\mathrm{O}^{\prime}-\mathrm{b}^{\prime}$ 曲線の下の面積を差し引く。す なわち, Fig. 7 (b) の多角形 $\mathrm{OBb}^{\prime} \mathrm{O}^{\prime}$ の面積のみを皮膜の はく離に用いられるエネルギーとする。なお，WC-Co 皮 膜で膜厚が薄い場合には，Fig. 4 (a) および Fig. 6 に示し たように, 圧子が基材に押し込まれたのちに荷重が急減 してはく離が生じるので, 同様に基材の変形に要するエ

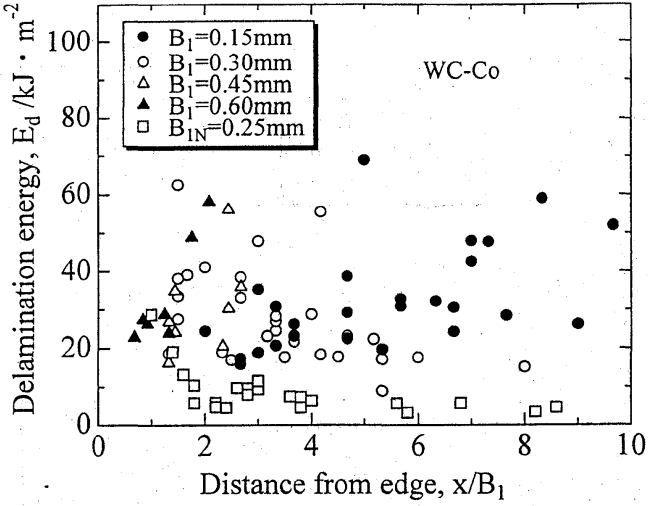

Fig. 10. Relation between normalized distance from edge and delamination energy for WC-Co coating.

ネルギーを差し引く．また，はく離面の形状を頂角 $2 \theta$ の 2 等辺三角形で近似すると，はく離に用いられたエネ ルギーは近似的に上記全エネルギーのうちの $2 \theta / 2 \pi$ とな る.したがって，はく離エネルギー $E_{d}$ を次式で表す。

$$
\begin{aligned}
& E_{d}=\frac{\int_{0}^{\delta_{0}} P d \delta-\int_{0}^{\delta_{0}-B_{1}} P^{\prime} \cdot d \delta}{S} \times \frac{2 \theta}{2 \pi} \\
& \theta=\tan ^{-1} \frac{S}{x^{2}}
\end{aligned}
$$

ここで, $S$ ははく離面積, $x$ はエッジからインデンテ ーション位置までの距離， $\delta_{0}$ は最大荷重点（A点）また は折れ曲がり点（B 点）までの変位であり，圧子が基材 に達する前にはく離が起こる場合には，上式の分子の第 2 項は不必要である. 本研究では, $x$ と $S$ は, 投影機を 用いて測定した。

\section{3 実験結果および考察}

\section{3 - 1 WC-Co 高速フレーム溶射皮膜のはく離荷重, はく離面積およびはく離エネルギーに及ぼす膜 厚の影響}

Fig. 8 は, 膜厚の異なる WC-Co 皮膜について, エッジ からの距離 $x$ を変化させてインデンテーション試験を行 い，はく離時の荷重 $P_{0}$ を調べた結果である，この困に よると, $B_{1}$ で無次元化したエッジからの距離 $x / B_{1}$ の増 加に伴い, $P_{0}$ はほぼ直線的に増加し，同じ $x / B_{1}$ では膜 厚 $B_{1}$ が大きいほど $P_{0}$ が大きいことが分かる．また，膜 厚が同程度で, ブラストを施していない試験片（ $B_{1}=$ $0.25 \mathrm{~mm}$ ，白四角印）とブラストを施した試験片 $\left(B_{1}=\right.$ $0.30 \mathrm{~mm}$ ，白丸印) を比較すると，ブラストを施していな い試験片のはく離荷重はかなり低い.

Fig. 9 は，エッジからの距離 $x$ と， はく離面積 $S$ の関 係を求めたものである. はく離形状（頂角の大きさ, 辺 の形状）の不規則性により，はく離面積のばらつきはか なり大きい. 皮膜厚さ $B_{1}=0.30 \sim 0.60 \mathrm{~mm}$ の場合に比心゙ $B_{1}=0.15 \mathrm{~mm}$ の場合の方が，はく離面積はやや大きいよ うであるが，とくに大きな有意差はない。 また，ブラス トを施したものと施していないもののはく離面積の差は 明瞭でない。は離面を 2 等辺三角形で近似したとき, 頂角 $2 \theta$ が $x$ によらず一定であれば, $S$ は距離 $x$ の 2 乗に 


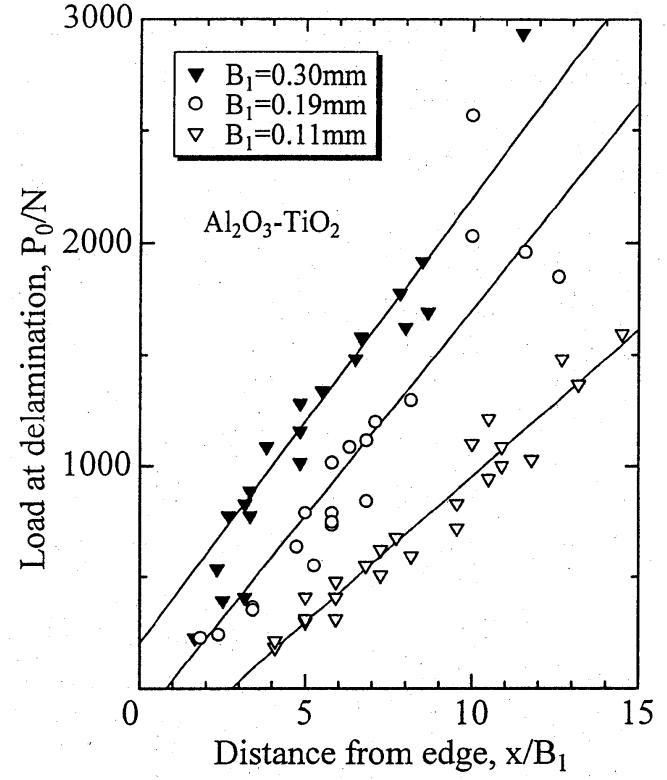

Fig. 11. Effect of coating thickness on the relation between normalized distance from edge and load at delamination for $\mathrm{Al}_{2} \mathrm{O}_{3}-\mathrm{TiO}_{2}$ coating.

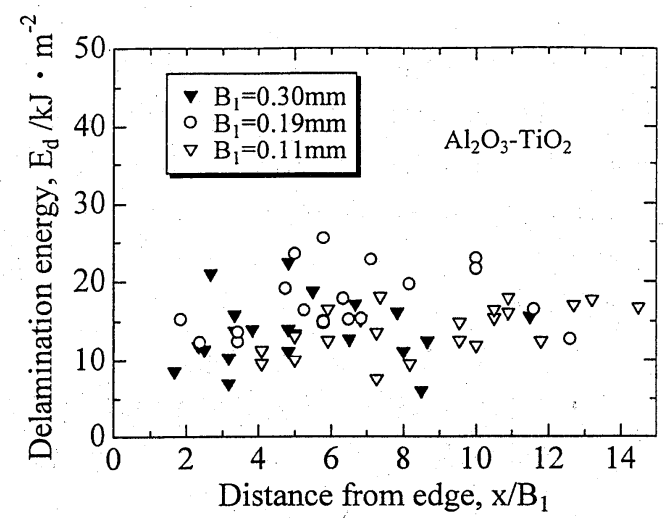

Fig. 12. Relation between normalized distance from edge and delamination energy for $\mathrm{Al}_{2} \mathrm{O}_{3}-\mathrm{TiO}_{2}$ coating.

比例して増加するはずである. 図中の放物線は実験デー タを最小二乗法により近似したものであり,この曲線か ら逆にはく離頂角 $2 \theta$ の平均值を求めると 143 度となる.

Fig. 10 は， $x / B_{1}$ とはく離エネルギー $E_{d}$ の関係を求め たものである。この図によると, ショットブラストを施 したものの中には著しくはく離エネルギーの高いものが あるが，これは，Fig .9 に示したように，はく離面積が 著しく小さかったためである. 大部分のはく離エネルギ 一は $x / B_{1}$ および膜厚によらず，ばらつきの範囲内でほ ぼ一定值となっている $\left(P_{0}\right.$ と $x / B_{1}$ の関係打よび $\delta_{0}$ と $x / B_{1}$ の関係が原点を通る直線関係で表され，また $S \propto x^{2}$ であれば， $E_{d}$ は $x / B_{1}$ によらず一定となる)。したがって これらの值を皮膜のはく離エネルギーとして採用すると， それらは安全側の值を与えることになる。 なお，WC-Co 皮膜のはく離エネルギーが膜厚にあまり依存しないとい う傾向は, 前報》の引張りによるせん断はく離試験の結
果（ただし，基材は焼なましした SKD62）と一致して いる。ブラストを施したものは，ブラストを施していな いものに比べてはく離エネルギーが大きいが，これはブ ラストを施すと基材表面に回凸ができるため皮膜と試験 片の接触面積が増えることと，せん断荷重が皮膜に水平 方向にかかるため, 皮膜の界面と基材の界面がブラスト による凹凸で引っかかるアンカー効果が原因と考皇られる。

\section{$3 \cdot 2 \quad \mathrm{Al}_{2} \mathrm{O}_{3}-\mathrm{TiO}_{2}$ プラズマ溶射皮膜のはく離エネル} ギーに及ぼす膜厚の影響

Fig. 11 は, $\mathrm{AI}_{2} \mathrm{O}_{3}-\mathrm{TiO}_{2}$ 皮膜について, エッジからの 無次元化距離 $x / B_{1}$ とはく離荷重 $P_{0}$ の関係を調べた結果 である.この場合も $x / B_{1}$ の増加とともに $P_{0}$ はほぼ直線 的に増加して扔り，同じ $x / B_{1}$ に対しては膜厚 $B_{1}$ が大き いほど $P_{0}$ が大きい，な抽，インデンテーション試験のの ち, はく離面積 $S$ を測定したところ, WC-Co 皮膜の場合 と同様, $S$ はエッジからの距離 $x$ の二乗にほほ比例して 増加した。曲線から求めた平均はく離頂角は約 113 度て あり, WC-Co 皮膜の頂角の平均值 143 度より小さかった.

つぎに,インデンテーション曲線からはく離エネルギ 一を求め（基材の変形に必要なエネルギーを差し引いた 值)，これをはく離面積で除した $E_{d}$ と無次元化したエッ ジからの距離 $x / B_{1}$ の関係を Fig. 12 に示す．この図によ ると, $E_{d}$ は $x / B_{1}$ の増加に対してわずかに変化している。 したがって，どの厚さの皮膜ではく離強度が大きいかの 順位づけ打よびはく離強度の值の決定が困難となるが, 傾向としては, $B_{1}=0.11 \mathrm{~mm}$ の場合より $B_{1}=0.19 \mathrm{~mm}$ お よび $0.30 \mathrm{~mm}$ の方が $E_{d}$ が大きい．前報6) の張試験によ るはく離エネルギー測定結果によると, やはり $B_{1}=$ $0.11 \mathrm{~mm}$ よりも $B_{1}=0.19 \mathrm{~mm}$ 打よび $0.30 \mathrm{~mm}$ の場合の方 がはく離エネルギーが大きくなっており（ただし， $B_{1}$ が さらに厚くなると，はく離エネルギーはかえって低下す る)，はく離エネルギーの膜厚依存性は類似している。 ま た, $E_{d}$ の值は，WC-Co 皮膜の場合よりかなり小さいが, この傾向も前報 ${ }^{6), 7)}$ の結果と一致している.

\section{$3 \cdot 3$ エッジインデンテーション法の利点および欠点}

この方法の利点としてはつぎのことがあげられる.

A-1 ぜい性皮膜は，延性皮膜と異なり，せん断はく離 を生じさせること自体が困難であるが，この方法を用い ると，せん断型のはく離を容易に起こさせることができる．

A-2 基材の硬度に無関係に適用できるので，金型や ロールなどの硬質基材の皮膜はく離強度の評価にも適用 できる。

A-3 測定装置が簡単である. 試料寸法も小さくてす み, 実際の部品から試験片を切り出すことにより, 容易 に試験ができる。

A-4 はく離までに要するエネルギーを求めるので, 定 量評価が可能である。

$\mathrm{A}-5$ はく離エネルギー $E_{d}$ が $x / B_{1}$ にあまり依存しない．

A-6 この試験システムを小型化するか, 既存の微小硬 度計（荷重 - 变位曲線が測定可能なもの）を用いれば, $\mathrm{PVD}, \mathrm{CVD}$ などで製造したセラミック薄膜のはく離強 度評価に適用できる可能性がある。 
一方，問題点としては，つぎのようなことがある.

B-1 はく離荷重（および変位）にはあまり大きなばら つきはないが，はく離面積に大きなばらつきがあり，そ の結果はく離エネルギー $E_{d}$ の值がかなりばらつく.し たがって測定点を多数とる必要がある.

B-2 あまりエッジに近い点に圧子を押し込むと，エッ ジ作製時の放電加工および砥石切断時のエッジ界面損傷 が測定值に影響する可能性がある。また，はく離エネル ギーが $x / B_{1}$ によって変化する場合には, どの位置での はく離エネルギーをその皮膜のはく離エネルギーとする かが決定しにくい.

B-3 WC-Co 皮膜と $\mathrm{Al}_{2} \mathrm{O}_{3}-\mathrm{TiO}_{2}$ 皮膜を比較すると, 同じ荷重であっても後者の方が変位が大きい.したがっ て変形しやすい皮膜でははく離エネルギーが非常に大き くなる可能性がある.

B-1 の理由は, 皮膜の割れおよびはく離き裂の進展方 向が一定ではなく, 皮膜のはく離面積が確率的に大きな 変動を生じるためと考えられる。たとえば，はく離荷重 が同程度で，はく離面積が極端に小さい場合には，三角 形はく離面の両側または片側の界面ですでにはく離が生 じていた可能性がある。はく離エネルギーの表現式にお いて， $S$ が小さくなれば $2 \theta$ も小さくなり，Sのばらつき の影響はある程度緩和されるが実際にはやはり $E_{d}$ のば らつきは大きい. 現段階では， $E_{d}$ の極端に大きい值は除 外し, $E_{d}$ の小さい值を安全側のはく離エネルギーとして 採用するのが適当と考えられる.

B-2 については，エッジの近傍の損傷の影響を避ける ため $x / B_{1}$ の值を大幅に変化させて実験し,$x / B_{1}>2$ のデ 一タを採用する。ももし $E_{d}$ が $x / B_{1}$ に依存して一定でない 場合には，その最低值をとるのがよいと思われる。

B-3 については，圧子の押し込みによって皮膜をはく 離させるエネルギーを用いる限り，これに皮膜および界 面の変形特性が含まれる。たとえばぜい性材料であって も多孔質であれば同じ圧子荷重に対して, 圧入変位は大 きくなる．このことは一般に変形しやすい皮膜ははく離 までにエネルギーを吸収し，はく離しにくいという概念 と矛盾しない.

エッジインデンテーション法におけるはく離強度評価 の最大の特徴は, 皮膜にエッジを設けると, 圧子の押し 込みにより皮膜がせん断はく離しやすくなるという現象 を利用することであり，基材の硬度に無関係に適用でき る. 皮膜に圧子を押し込むと, 皮膜は不可逆変形すると ともに，圧子の頂角が大きいので圧子直下の皮膜は基材 に押しつけられ，その外側にき裂が発生して皮膜がせん 断はく離する。.また，はく離過程は，エッジの存在，皮 膜と基材の異種材料の相互作用，皮膜および界面におけ るき裂の発生と伝ぱなど, 複雑な変形および破壊過程を 内包している.したがって，エッジインデンテーション 法で求めるはく離エネルギーの物理的内容は複雑である.

圧子の押し込み過程を, 圧子近傍におけるき裂の発生 に必要な作業と考え, その後のき裂伝ぱ挙動からき裂の 界面伝ぱ抵抗を求めることも考えられるが，そのために
は, 皮膜に加わるせん断力と発生したき裂長さの情報が 必要である。しかしながら現段階では, 圧子近傍で発生 したき裂が，どの程度の長さになったときに不安定伝ぱ するかを荷重一変位曲線から求めることはできない。し たがって，この方法に打ける破壊力学的な定量化，たと えば, 臨界エネルギー解放率または界面破壊じん性を推 定することは今後の課題である.

\section{4 結}

焼入れ後焼戻した熱間加工用合金工具鋼（JIS：SKD5） 試験片に WC-Co 粉末を高速フレーム溶射した。 また一 般構造用圧延鋼材（JIS：SS400）試験片に $\mathrm{A1}_{2} \mathrm{O}_{3}-\mathrm{TiO}_{2}$ 混合粉末をプラズマ溶射した。これら溶射試験片にエッ ジインデンテーション試験を行い, 荷重 - 変位曲線から はく離エネルギー $E_{d}$ を求めた．得られた結果はつぎの 通りである。

（1）はく離荷重は，エッジからの距離 $x$ を皮膜厚さ $B_{1}$ で無次元化した $x / B_{1}$ の増加に伴い直線的に増加す る.はく離面積のばらつきは大きいが, はく離面積はエ ッジからの距離 $x$ の 2 乗にほぼ比例して増加する.

（2）WC-Co 皮膜のはく離エネルギーは膜厚および $x / B_{1}$ に依存せず，ばらつきの範囲内でほぼ一定となる. ブラストを施していない試験片のはく離エネルギーは低い.

(3) $\mathrm{Al}_{2} \mathrm{O}_{3}-\mathrm{TiO}_{2}$ 皮膜のはく離エネルギーは WC-Co 皮 膜より低い.

(4) 本研究で提案したエッジインデンテーション法に より溶射皮膜のせん断はく離強度を定量的に評価できる.

おわりに，本研究に熱心に協力された杉川匡信君（当 時学生）および試験装置を製作していただいた広田秀徳 技官に感謝します。 また，試験片の溶射でお世話になり ました広島県立西部工業技術センター生産技術部の蒲田 政信部長および原 信彦主任研究員に感謝します。なお, 本研究を行うに当たり, (財) 谷川熱技術振興基金の平成 8 年度研究援助金を使用させていただきました。ここに 謝意を表します。

(平成 9 年 5 月 23 日日本材料学会第 46 期学術講演会にて講演)

\section{参 考 文 献}

1) 竹田博光編, “セラミックコーティング”（1988）日刊工 業新聞社.

2）原田良夫，日本金属学会会報， 31，413（1992）。

3) JIS H8661-1994：亜鉛溶射皮膜試験方法，JIS H86631994 ：アルミニウム溶射皮膜試験方法, JIS H8666-1994 : セラミック溶射皮膜試験方法.

4) 伊藤義康, 柏谷英夫, 機械の研究, 41, 701 (1989).

$5 ）$ 伊藤義康, 斎藤正弘, 栢谷英夫, 機械の研究, 42,377 (1990).

6) 中佐啓治郎, 高田宗一郎, 市後博造, 材料, 44,321 (1995).

7) 中佐啓治郎, 加藤昌彦, 江河史晃, 蒲田政信, 原 信彦, 材料, 45, 680 (1996).

8 ）加藤昌彦, 中佐啓治郎, 江河史晃, 蒲田政信, 原 信彦, 材料, 46, 315 (1997). 